\title{
Optimization of the Composition and Process of Preparation of Hot-pressed Ceramics with Increased Characteristics Based on Boron Carbide
}

\author{
V.M. Volkogon ${ }^{1}$, S.K. Avramchuk ${ }^{1}$, V.V. Kovalchuk ${ }^{1}$ A.V. Kravchuk1, A.V. Stepanenko ${ }^{1}$, D.A. Kotliar ${ }^{1}$, \\ T.V. Pavlychuk ${ }^{1}$, T.M. Kutran ${ }^{1}$, V.S. Antonyuk ${ }^{2}$, K.I. Avramchuk ${ }^{2}$ \\ ${ }^{1}$ Frantsevich Institute for Problems in Materials Science, National Academy of Sciences of Ukraine, \\ 3, Krzhizhanovsky St., 03142 Kyiv, Ukraine \\ 2 National Technical University of Ukraine "Igor Sikorsky Kyiv Polytechnic Institute", 37, Peremogy Ave., \\ 03056 Kyiv, Ukraine
}

(Received 03 May 2020; revised manuscript received 20 December 2020; published online 25 December 2020)

\begin{abstract}
The optimal composition and conditions for obtaining hot-pressed ceramics based on powders of technical boron carbide, which has high physical and mechanical properties and can be effectively used in extreme operating conditions, are determined. The influence of activating impurities in the form of oxides in the composition of the initial charge on the formation of the composite material structure in the process of hot pressing is experimentally established. X-ray diffraction analysis of heterophase ceramics which is formed is carried out and it is shown that in the process of hot pressing of ceramics, borides of the corresponding oxides are formed, refining of ceramics with the emergence of secondary structures takes place, and heterogeneous state of the formed ceramics provides a high level of structural characteristics. It is established that the use of activating impurities in the form of $\mathrm{Cr}_{2} \mathrm{O}_{3}, \mathrm{TiO}_{2}$ and $\mathrm{SiO}_{2}$ oxides provides the possibility of using industrial technical powders of boron carbide with high free carbon content in the production of ceramics with fine-grained structure and high mechanical properties $\left(G_{z g}=600-800 \mathrm{MPa}\right)$ in a wide temperature range.
\end{abstract}

Keywords: Boron carbide, Activating impurities, Hot pressing, X-ray analysis, Stress-strain state, Density, Flexural strength, Hardness, Microstructure.

DOI: 10.21272/jnep.12(6).06034

PACS number: 42.79.Bh

\section{INTRODUCTION}

Currently, there is a high demand for products, the main requirement for which is the resistance to various types of wear. The development of high-strength structural ceramics for diferent purposes, especially for the use in extreme operating conditions in various fields of technology is one of the traditional areas of research at the I.M. Frantsevich Institute for Problems of Materials Science of the National Academy of Sciences of Ukraine [1].

The study of the peculiarities of the formation of a complex of physical-mechanical and service characteristics of composite materials based on carbides and borides of refractory compounds is the basis of technological approaches to creating ceramics with the necessary properties $[2-5,7,8]$.

The production of high-density composites based on boron carbide is associated with a fairly high energy cost and requires compliance with certain requirements for the state of the initial powders. Previous research [9] performed at the Institute of Materials Science of the National Academy of Sciences of Ukraine found that regardless of the characteristics of the initial powders obtained by different methods, single-phase hot-pressed ceramics of boron carbide has a heterogeneous structure and high porosity. In addition, it is shown that the corresponding technological operations can adjust the structure and, accordingly, the properties of single-phase ceramics, but this is not enough to obtain materials with a high level of physical and mechanical properties. It is especially difficult to obtain single-phase ceramics based on technical boron carbide powders with a sufficient level of physical and mechanical characteristics, which, as a rule, contains a relatively large amount of free carbon.

The production of high-strength ceramics based on boron carbide can be simplified by finding the composition of additives in the initial charge, which contribute to the formation of high-density heterophase material with a high stable level of physical and mechanical properties (modulus of elasticity, toughness, etc.) $[2-5,7,8]$.

In this work, the choice of activating additives for technical powder of boron carbide was made on the basis of the influence of physicochemical properties of the initial powders and hot pressing conditions on the structure and physico-mechanical characteristics of the heterophase materials. The results allowed to formulate the basic requirements for activating impurities, which make it possible to use as a base material technical powders of boron carbide. Activating additives help to reduce the pressure, temperature and isothermal holding time of hot pressing, the binding of free carbon and the formation of other phases with the appropriate mechanical properties.

The aim of the work is to optimize the composition and process of obtaining hot-pressed ceramics with high characteristics based on boron carbide.

Given the basic principle of forming high-strength ceramics with $\mathrm{B} 4 \mathrm{C}$, which is based on the use of activating additives, research was aimed at establishing the optimal composition and technological conditions of composite ceramic materials with high physical and mechanical characteristics, which can form the basis of scientific and technological concept of their formation. 


\section{CHARACTERISTICS OF MATERIALS, EXPERIMENTAL AND RESEARCH METHODS}

The studies used two batches of initial technical powders of boron carbide obtained by the method of carbon-thermal reduction of boron anhydride. They differed in chemical composition, primarily in the content of fixed carbon and its presence in the free state, as well as the content of impurities. The first batch of powders had the following chemical composition: $\quad \mathrm{B}_{\text {gen }}=71.7$ wt. \%,$\quad \mathrm{C}_{\text {linked }}=26.4$ wt. \%, $\mathrm{C}_{\text {free }}=1.3$ wt. $\%, \quad \mathrm{Fe}=0.2$ wt. $\%, \quad(\mathrm{Mg}, \mathrm{Ti}), \mathrm{B}_{2} \mathrm{O}_{3}$ and $\mathrm{Fe}=0.05$ wt. $\%$. The second batch was characterized by the following chemical composition: $\mathrm{B}_{\text {gen }}=78.7 \mathrm{wt} . \%$, $\mathrm{C}_{\text {linked }}=21.2$ wt. $\%, \mathrm{~B}_{2} \mathrm{O}_{3}$ and $\mathrm{Fe}=0.05$ wt. $\%$.

Powders of the first batch of boron carbide in the initial state were subjected to grinding using a planetary mill, after which they, depending on the duration of the grinding process, had the following characteristics.

- With the duration of grinding the powders of the first batch $\tau=1.5 \mathrm{~h}$, the average particle size was $22.0 \mu \mathrm{m}$. The increase in the duration of grinding to $\tau=3.5 \mathrm{~h}$ provides an average particle size of the powder up to $15.0 \mu \mathrm{m}$ and a further increase in the grinding process does not significantly affect the change in the dispersion of the powders;

- Grinding the powder of the second batch for $\tau=2.0 \mathrm{~h}$ provides an average particle size of the powder of $2.6 \mu \mathrm{m}$.

Chemical analysis of impurities in the original powders of boron carbide was carried out according to the method "Boron carbide and charge based on it" (M066084) developed at the Institute of Natural Sciences of the National Academy of Sciences of Ukraine.

The particle size distribution of the powder was determined using the device "Culter T-2", and the specific surface area - by the device "Akusorb 2100".

$\mathrm{X}$-ray diffraction analysis of $\mathrm{B}_{4} \mathrm{C}$ powders was performed using an upgraded Drone-3 diffractometer by the method of spot shooting with a step of $0.05^{\circ}$ and holding time at a point of $4 \mathrm{~s}$. The diffraction pattern of boron carbide powder of the first batch is shown in Fig. 1.

When determining the periods of the boron carbide lattice, the shooting step was $0.02^{\circ}$ and the exposure time was increased to $15 \mathrm{~s}$.

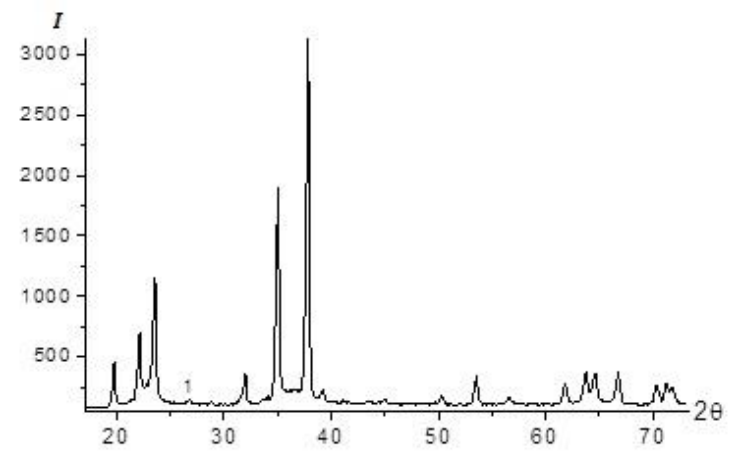

Fig. 1 - Diffractogram of the initial boron carbide powder: 1 - free carbon
The amount of free carbon was determined as the ratio of the total intensity of the (002) lines of soot and graphite to the intensity of the (110) lines of boron carbide. To determine the amount of fixed carbon in the powders, X-ray were performed of several lines of boron carbide powder with a silicon standard were performed. Using the values of $2 \theta$ diffraction maxima calculated for several reflection planes of boron carbide found from the survey results, the parameters of the hexagonal lattice $a$ and $c$ were determined. The content of fixed carbon in the samples of boron carbide powders was calculated depending on the lattice parameter of boron carbide on the concentration of fixed carbon.

Hot pressing of ceramic samples based on boron carbide was carried out in molds made of graphite brand MPG-7, which has high physical and mechanical properties.

To eliminate the interaction of powders with the graphite mold in the process of hot pressing on its walls a protective layer of coating based on boron nitride was applied.

Samples of ceramics were obtained on a hot pressing unit based on a hydraulic press P-125 using a thyristor frequency converter GPCHS-120 for heating. The density of the obtained ceramic samples with a size of $5 \times 5 \times 50 \mathrm{~mm}$ was determined by hydrostatic weighing. The measurement error of the obtained values of the density of the samples was 10-4 units. The microstructure of the composites was studied using a metallographic microscope MIM-8. Vickers hardness was measured at an indenter load of $200 \mathrm{~N}$.

The level of residual stresses in sintered composite ceramics was calculated using the statistical theory developed by Khoroshun L.P. [6].

\section{DISCUSSION OF RESEARCH RESULTS}

The results of process studies for obtaining monophase ceramics based on boron carbide indicate that the level of its physical and mechanical characteristics does not exceed the strength of singlephase ceramics based on boron carbide $\left(\sigma_{z g}=400 \mathrm{MPa}\right.$ and $E=410 \mathrm{GPa}$ ), while samples of synthesized boron carbide powder are under the conditions of compliance with the carbon content of stoichiometric composition ( $\sigma_{z g}=420 \mathrm{MPa}$ and $E=415 \mathrm{GPa}$ ) [10].

The inhibitory factor in obtaining hot-pressed ceramics with high physical and mechanical properties is the presence of a significant amount of free carbon in technical powders of boron carbide.

Due to the fact that obtaining monophase ceramics based on $\mathrm{B}_{4} \mathrm{C}$ with maximum physical and mechanical characteristics is possible in a narrow range of hotpressing temperatures $\left(T_{s}=1150-1180^{\circ} \mathrm{C}\right)$ [10], the exact provision of which is practically impossible, it is reasonable to obtain ceramics of heterophase composition by the introduction into the charge of oxides based on $\mathrm{B}_{4} \mathrm{C}$, which provides the ability to expand the temperature range of the hot-pressing process.

This physicochemical approach provides the possibility of using, to obtain new ceramic materials, modes of reaction hot pressing, in which in the process of chemical reactions of boron and carbothermal reduction, the structure and phase composition of the 
material is formed and refined with removal of unwanted impurities.

The presence of a significant amount of free carbon in boron carbide powders is an inhibitory factor in obtaining hot-pressed ceramics with high physical and mechanical characteristics.

Studies of the phase composition and microstructure of samples obtained from the charge with the addition of $\mathrm{TiO}_{2}, \mathrm{Cr}_{2} \mathrm{O}_{3}$, and $\mathrm{SiO}_{2}$ revealed that in the process of reaction sintering under hot pressing there is a chemical interaction between these oxides and carbon according to the following reactions:

$$
\begin{gathered}
2 \mathrm{TiO}_{2}+\mathrm{B}_{4} \mathrm{C}+3 \mathrm{C}=2 \mathrm{TiB}_{2}+4 \mathrm{CO} \\
\mathrm{Cr}_{2} \mathrm{O}_{3}+\mathrm{B}_{4} \mathrm{C}+2 \mathrm{C}=2 \mathrm{CrB}_{2}+3 \mathrm{CO} \\
\mathrm{SiO}_{2}+3 \mathrm{C}=\mathrm{SiC}+2 \mathrm{CO}
\end{gathered}
$$

Activating additives in the form of titanium $\mathrm{TiO}_{2}$, chromium $\mathrm{Cr}_{2} \mathrm{O}_{3}$ or silicon $\mathrm{SiO}_{2}$ oxides make it possible to use technical powders of boron carbide with a high content of free carbon to obtain high-strength ceramics with a phase composition of $\mathrm{B}_{4} \mathrm{C}-\left(\mathrm{TiB}_{2}, \mathrm{CrB}_{2}\right)$ or $\mathrm{B}_{4} \mathrm{C}-\mathrm{SiC}$.

Due to the fact that in the process of hot pressing there is a chemical interaction between the components of mixtures, which involves oxide phases of activating impurities accompanied by significant gas evolution in the form of volatile compounds, so the process was carried out with isothermal exposure at each intermediate stage. It includes preheating to a given temperature of the mold and powder mixture, removing fusible components and gaseous products, and direct sintering under a given pressure at a given temperature to the maximum compaction, followed by cooling of the mold together with the samples.

The value of the minimum temperature of the beginning of active consolidation at hot pressing depends on a kind of impurity. When $\mathrm{TiO}_{2}$ is introduced, it is $T_{s}=2173 \mathrm{~K}$, and for $\mathrm{Cr}_{2} \mathrm{O}_{3}$ it is within $T_{s}=2373 \mathrm{~K}$. The minimum temperature $T_{s}=1973 \mathrm{~K}$ of the beginning of active consolidation at hot pressing is characterized by the charge which contains an impurity in the form of a mixture of $\mathrm{SiO}_{2}$ and carbon.

This circumstance is due to the formation of the liquid phase and subsequent processes of chemical interaction of silicon oxide with carbon, which are accompanied by the formation of another phase.

Physico-mechanical and operational characteristics of heterophase ceramics are largely determined by the stress-strain state of the samples. Determination of the optimal amount of activating impurities in the process of hot pressing of heterophase ceramics was carried out on the basis of residual stress calculations in compositions based on boron carbide using selected oxides. Estimation of the stress-strain state of heterophase ceramics was performed by calculating the residual stresses in the samples, according to which the matrix phase of boron carbide is under the action of compressive stresses and isolated inclusions of impurities in the stretched state that creates preconditions for high strength and performance.

The resulting stress state of the composition depends on the volume content of its components and is determined by the technological parameters of the hot pressing process.
Fig. 2 shows the nature of the formation of strength indicators of heterophase ceramics depending on the number of activating impurities.

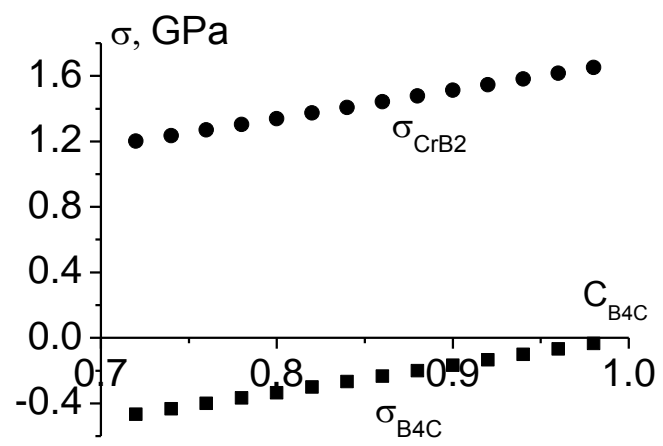

Fig. 2 - The nature of the formation of strength indicators of heterophase ceramics $\left(\mathrm{B}_{4} \mathrm{C}+\mathrm{CrB}_{2}\right)$ depending on the number of activating impurities

To obtain ceramics of heterogeneous composition with high mechanical properties, a study was performed on the influence of the content of various process-activating impurities and optimization of their number in the charge during sintering of ceramics.

Experimentally, during hot pressing $\left(T=2100{ }^{\circ} \mathrm{C}\right)$ [11] of heterophase ceramics of the $\mathrm{B}_{4} \mathrm{C}-\mathrm{Cr}_{2} \mathrm{O}_{3}$, system, the following parameters were obtained (Table 1), which is characteristic of heterophase ceramics [12].

Table 1 - Physico-mechanical characteristics of heterophase ceramics depending on the type of the content of activating impurities

\begin{tabular}{|c|c|c|c|} 
Sample & Density & $\begin{array}{c}\text { Hardness } \\
\text { HV, GPa }\end{array}$ & $\begin{array}{c}\text { Bending } \\
\text { strength, MPa }\end{array}$ \\
\hline $\mathrm{B}_{4} \mathrm{C}+10$ wt. \% $\mathrm{Cr}_{2} \mathrm{O}_{3}$ & 2.54 & 19.46 & 802 \\
\hline $\mathrm{B}_{4} \mathrm{C}+20$ wt. \% $\mathrm{Cr}_{2} \mathrm{O}_{3}$ & 2.58 & 18.81 & 663 \\
\hline $\mathrm{B}_{4} \mathrm{C}+30$ wt. $\% \mathrm{Cr}_{2} \mathrm{O}_{3}$ & 2.79 & 16.12 & 550 \\
\hline
\end{tabular}

They indicate that the amount of activating impurities in the production of hot-pressed ceramics based on boron carbide with maximum strength should be within $15 \%$ of the mass.

Fig. 3 shows the diffraction pattern of samples of sintered heterophase ceramics of the composition $\mathrm{B}_{4} \mathrm{C}+$ 10 wt. $\% \mathrm{Cr}_{2} \mathrm{O}_{3}$ based on boron carbide powders of the second batch. According to calculations, the samples contained 85 wt. $\% \mathrm{~B}_{4} \mathrm{C}, 6 \mathrm{wt} \%$ carbon and 9 wt. \% mixture of chromium borides $\left(\mathrm{CrB}_{2}+\mathrm{Cr}_{5} \mathrm{~B}_{3}\right)$.

It should be noted that the results of X-ray diffraction analysis of samples of hot-pressed ceramics $\mathrm{B}_{4} \mathrm{C}+\mathrm{Cr}_{2} \mathrm{O}_{3}$ found that in the samples there is the formation of chromium borides, mainly $\mathrm{CrB}_{2}$ (Fig. 4).

When preparing mixtures for hot-pressed ceramics, it is more efficient to use mixtures of oxides in a certain ratio, for example, to use $5 \mathrm{wt}$ \% titanium oxide, $\mathrm{Ti}_{2}-\mathrm{Cr}$ solid solution with possible replacement of titanium atoms and borides by chromium atoms in the manufacture of ceramics $\mathrm{B}_{4} \mathrm{C}+\mathrm{Cr}_{2} \mathrm{O}_{3}$. It should also be noted that free carbon is present in all samples (Fig. 5).

The results of determining the physical and mechanical characteristics of such heterophase ceramics are shown in Table 2. 


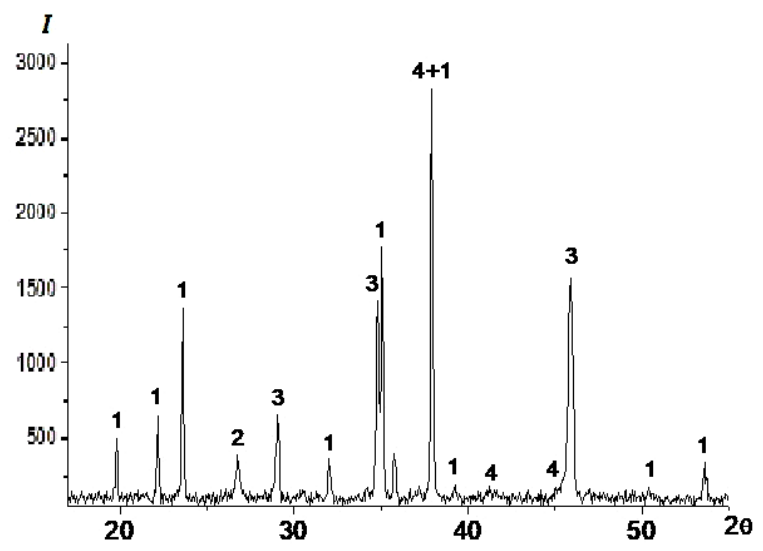

Fig. 3 - Diffraction pattern of the composition $\mathrm{B}_{4} \mathrm{C}+10$ wt. \% $\mathrm{Cr}_{2} \mathrm{O}_{3}$ : 1 - boron carbide; 2 - graphite; $3-\mathrm{CrB}_{2} ; 4-\mathrm{Cr}_{5} \mathrm{~B}_{3}$

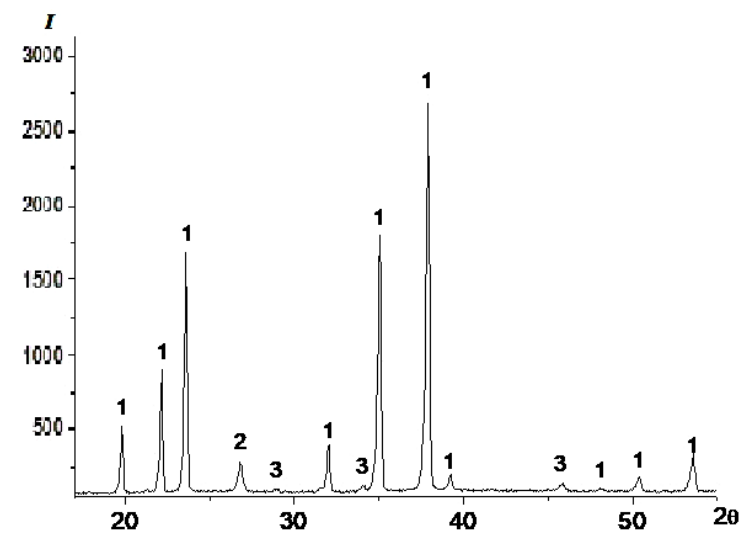

Fig. 4-Diffraction pattern of the sample based on boron carbide $\mathrm{B}_{4} \mathrm{C}+10$ wt. $\% \mathrm{Cr}_{2} \mathrm{O}_{3}: 1$ - boron carbide; 2 - graphite; $3-\mathrm{CrB}_{2}$

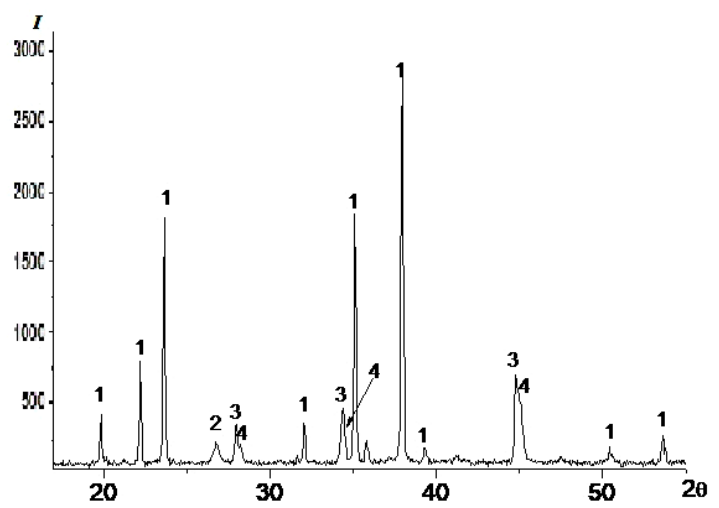

Fig. 5 - Diffractogram of a sample of hot-pressed ceramics based on boron carbide composition: $\mathrm{B}_{4} \mathrm{C}+5 \mathrm{wt}$. $\% \mathrm{TiO}_{2}+2$ wt. $\%$ $\mathrm{Cr}_{2} \mathrm{O}_{3}: 1$ - boron carbide; 2 - graphite; 3 - Ti (Cr); $4-\mathrm{Cr}_{3} \mathrm{~B}_{4}$

Table 2-Hardness and crack resistance of heterophase ceramics at a load of $200 \mathrm{~N}$

\begin{tabular}{c|c|c|} 
Sample B 4 C, batch 2 & $\mathrm{HV}_{200 \mathrm{~N}}, \mathrm{GPa}$ & $K_{1 \mathrm{c}}, \mathrm{MPa} \cdot \mathrm{m}^{1 / 2}$ \\
\hline $\mathrm{B}_{4} \mathrm{C}+10$ wt. $\% \mathrm{Cr}_{2} \mathrm{O}_{3}$ & 19.46 & 4.75 \\
\hline $\begin{array}{c}\mathrm{B}_{4} \mathrm{C}+5 \text { wt. } \% \mathrm{TiO}_{2}+ \\
+2 \text { wt. } \% \mathrm{Cr}_{2} \mathrm{O}_{3}\end{array}$ & 21.06 & 4.19 \\
\hline
\end{tabular}

The study of the microstructure of such heterophase ceramics obtained in these systems shows that with a sufficiently large total content of residual free carbon and chromium boride in the ceramics, during indentation there are no chips of the material under the indenter, there are radial cracks and the maximum hardness is $19.46 \mathrm{MPa}$. The decrease in the total concentration of the second phases $\left(\mathrm{C}\right.$ and $\left.\mathrm{CrB}_{2}\right)$ in the material leads to the formation of petal cracks and chipping of the material in the indentation zone, which was confirmed in [12].

Fig. 6 shows the general view of the microstructure of heterophase ceramics $\mathrm{B}_{4} \mathrm{C}+10 \%$ and the imprint of the Vickers indenter at a load of $200 \mathrm{~N}(\times 600)$.

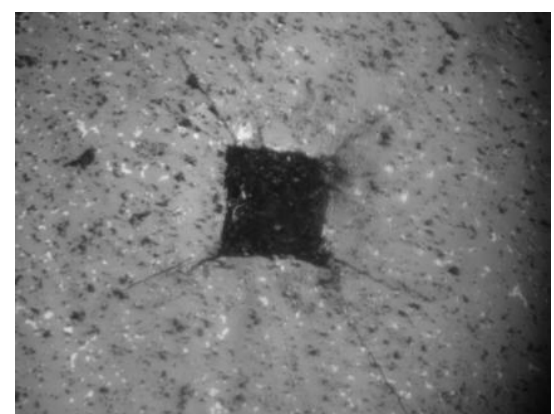

Fig. 6 - General view of the microstructure of heterophase ceramics $\mathrm{B}_{4} \mathrm{C}+10$ wt. $\% \mathrm{Cr}_{2} \mathrm{O}_{3}$ and the imprint of the Vickers indenter at a load of $200 \mathrm{~N}(\times 600)$

Indentation of ceramics of the ternary system showed an increase in hardness in comparison with previous samples of heterophase material at slightly lower values of crack resistance.

The general view of the microstructure of heterophase ceramics based on boron carbide is shown in Fig. 7 .

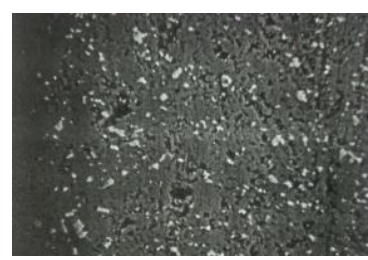

a

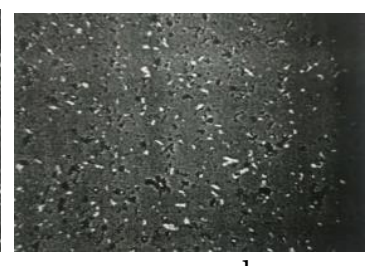

$\mathrm{b}$
Fig. 7 - Microstructure of heterophase ceramics samples based on boron carbide $(\times 1200): \mathrm{B}_{4} \mathrm{C}+10$ wt. $\% \mathrm{Cr}_{2} \mathrm{O}_{3}$ (a) and $\mathrm{B}_{4} \mathrm{C}+$ 5 wt. $\% \mathrm{TiO}_{2}+2$ wt. $\% \mathrm{Cr}_{2} \mathrm{O}_{3}$ (b)

The illustrations show that the use of activating impurities in the form of chromium and titanium oxides provides the possibility of using industrial technical powders of boron carbide with a high content of free carbon in the process of reactive hot pressing of ceramics with a fine-grained structure and high mechanical properties $\left(\sigma_{z g}=800-600 \mathrm{MPa}\right)$ in a wide range of hot pressing temperatures.

\section{CONCLUSIONS}

As a result of the conducted research of features of the heterophase ceramics formation on the basis of boron carbide, the following is established.

1. The use of activating additives $\mathrm{SiO}_{2}, \mathrm{TiO}_{2}$ and $\mathrm{Cr}_{2} \mathrm{O}_{3}$ helps to reduce the parameters of the process of hot pressing of ceramics (pressure, temperature and duration of isothermal exposure) providing highdensity heterophase ceramics. 
2. Based on the calculations of residual stresses in the samples of heterophase ceramics, it is established that the matrix phase of boron carbide is under the action of compression stresses and isolated inclusions of boride impurities in the stretched state, resulting in preconditions for high strength and performance of composites.

3 . In the process of reaction sintering of boron carbide with oxides, heterophase ceramics of $\mathrm{B}_{4} \mathrm{C}-(\mathrm{Si}, \mathrm{Ti}, \mathrm{Cr}) \mathrm{B}_{2}$ composition is formed, in the production of which it is possible to effectively use powders of technical boron carbide with a high content of free carbon. At the same time, ceramics of $\mathrm{B}_{4} \mathrm{C}-\left(\mathrm{CrB}_{2}+\mathrm{TiB}_{2}\right), \mathrm{B}_{4} \mathrm{C}-\mathrm{CrB}_{2}$ composition is formed, in which anomalous grain growth is inhibited and a fine-grained structure with a high level of mechanical properties is formed in the extended temperature range of the technological process in comparison with single-phase ceramics. Such ceramics have a bending strength of $600-800 \mathrm{MPa}$, which is twice the performance of single-phase ceramics made of boron carbide.

\title{
REFERENCES
}

1. O.N. Grigor'ev, Powder Metall. Met. C+ 51 No 11/12, 697 (2012).

2. V.M. Volkohon, Sci.-Practic. Conf. "Current issues. Ensuring service and combat activities of military formations and law enforcement agencies", 34 (31 October 2018: Kharkiv: 2018).

3. O.N. Grigor'ev, S.A. Lapko, E.G. Trunova, Refract. Ind. Ceram+ 46 No 3, 208 (2005).

4. V.R. Maslennikova, A.D. Panasyuk, L.I. Struk, et al., Powder Metall. Met. C+ 36 No 11/12, 570 (1997).

5. O.N. Grigor'ev, G. A. Gogotsi, Yu.G. Gogotsi, et al., Powder Metall. Met. C+ 39 No 5/6, 239 (2000).

6. O.N. Grigorev, B.I. Trefilov, L.P. Khoroshun, III All-Union Symposium "Technological Residual Stresses", 129 (Moscow: Publishing House of the USSR Academy of Sciences: 1988).

7. S.P. Dodd, G.A. Saunders, B. James, J. Mater. Sci. 37 No 13, 2731 (2002)

8. V. Domnich, S. Reynaud, R.A. Haber, M. Chhowalla, J. Am. Ceram. Soc. 94 No 11, 3605 (2011).

9. V.V. Koval'chuk, D.A. Kotlyar, V.M. Volkogon, et al., Powder Metall. Met. C+ 27 No 12, 981 (1988).

10. O.N. Hryhorev, B.A. Halanov, S.M. Yvanov, V.A. Kotenko, Physico-mechanical problems of modern materials science (Akademperiodika: 2013).

11. S. Wang, X.Yu. J. Zhang, Y. Zhang, et al., J. Superhard Mater. 36, 279 (2014).

12. V.M. Volkogon, V.S. Antonyuk, J. Superhard Mater. 23 No 5, 50 (2001).

\section{Оптимізація складу та процесу отримання гарячепресованої кераміки з підвищеними характеристиками на основі карбіду бору}

В.М. Волкогон ${ }^{1}$, С.К. Аврамчукํㅡㄹ В.В. Ковальчук ${ }^{1}$, А.В. Кравчук ${ }^{1}$, А.В. Степаненко Д.А. Котляр ${ }^{1}$, Т.В. Павличук ${ }^{1}$, Т.М. Кутрань ${ }^{1}$, В.С. Антонюк ${ }^{2}$, К.І. Аврамчук ${ }^{2}$

1 Інститут проблел матеріалознавства ілені І.М. Францевича Національної акаделї̈ наук Украӥни, вул. Кржижанівського, 3, 03142 Київ, Україна

2 Національний технічний університет Украйни "Київський політехнічний інститут ілені Ігоря Сікорського", просп. Порелоги, 37, 03056 Київ, Украӥна

\begin{abstract}
Визначено оптимальний склад та умови отримання гарячепресованої кераміки на основі порошків технічного карбіду бору, яка мае високі фізико-механічні властивості і може ефективно використовуватись в екстремальних умовах експлуатації. Експериментально встановлено вплив активуючих домішок у вигляді оксидів до складу вихідної шихти на формування структури композиційного матеріалу в процесі гарячого пресування. Виконано рентгено-дифракційний аналіз гетерофазної кераміки, яка утворюеться при цьому, та показано, що в процесі гарячого пресування кераміки утворюються бориди відповідних оксидів, має місце рафрінування кераміки з виникненням вторинних структур, а гетерогенний стан утворюваної кераміки забезпечуе отримання високого рівня структурних характеристик. Показано, що застосування активуючих домішок у вигляді оксидів $\mathrm{Cr}_{2} \mathrm{O}_{3}$, $\mathrm{TiO}_{2} \mathrm{i} \mathrm{SiO}_{2}$ забезпечуе можливість використання промислових технічних порошків карбіду бору з великим вмістом вільного вуглецю в процесі отримання кераміки з дрібнозеренною структурою та високим рівнем механічних властивостей $\left(G_{32}=600-800 \mathrm{MПа)} \mathrm{в} \mathrm{широкому} \mathrm{інтервалі} \mathrm{температур}\right.$ гарячого пересування.
\end{abstract}

Ключові слова: Карбід бору, Активуючі домішки, Гаряче пресування, Рентгенівський аналіз, Напружено-деформований стан, Густина, Міцність на згин, Твердість, Мікроструктура. 